\title{
Uji Eksperimen Efisiensi Kerja pada Rancangan Hydraulic Ram Pump dengan Water Hammer
}

\author{
Ayuni Nuraeni, Silvia Wulandari, Ulfa Hanifa Azzahra, Anisah R.M, \\ Resti Ardianti, Rifa'atul Maulidah* \\ Program Studi Pendidikan Fisika, Universitas Siliwangi, Tasikmalaya, Indonesia \\ *e-mail korespondensi: rifaatulm@unsil.ac.id \\ (masuk: 25-06-2020; revisi: 11-07-2020; diterima: 06-08-2020)
}

\begin{abstract}
Abstrak: Pada studi ini dilakukan uji eksperimen untuk mengetahui efisiensi kerja pada alat hydraulic ram pump (pompa hidram) yang memanfaatkan water hammer (palu air) untuk mengalirkan air dari tempat rendah ke tempat yang lebih tinggi secara mekanik. Pada uji eksperimen diberikan variasi tekanan air-masuk yang diukur dan dihitung dengan menggunakan Hukum Toricelli dan Persamaan Bernoulli. Efisiensi kerja dari rancangan hydraulic ram pump ini dicari dengan menganalisis debit air-limbah $\left(Q_{L}\right)$, debit air-naik $\left(Q_{N}\right)$, dan debit air-masuk $\left(Q_{M}\right)$. Nilai efisiensi kerja dinyatakan dalam persen yang dihitung dengan membandingkan antara $Q_{M}$ dengan $Q_{N}$. Dibandingkan pula nilai efisensi kerja dengan mengolah data volume air-naik dan volume air-masuk dalam tabel data untuk menemukan nilai persamaan garis linear $y=m . x$, diasumsikan efisiensi kerja hidraulic rum pump sebagai gradien garis $(m)$. Metode pengolahan data dalam uji eksperimen menggunakan metode statistik deskriptif kuantitatif. Hasil uji eksperimen diperoleh tekanan $98,156 \mathrm{~Pa}$ sebagai tekanan air-masuk yang baik berdasarkan pertimbangan kecepatan aliran air, waktu air-naik, dan volume airnaik yang lebih cepat dibandingkan variasi tekanan lainnya. Efisiensi kerja hydraulic ram pump yang dihasilkan pada tekanan $98,156 \mathrm{~Pa}$ adalah $46.5 \%$. Besar efisiensi kerja hasil uji eksperimen yang tidak mencapai nilai 100\% ini menunjukkan bahwa dengan menggunakan rancangan pompa ini masih banyak volume airterbuang selama proses pemompaan berlangsung.
\end{abstract}

Kata kunci: efisiensi kerja, hydraulic ramp pump, debit, volume

\section{PENDAHULUAN}

Suatu alat di sekitar manusia bisanya menukar energi menjadi kerja atau melakukan kerja untuk menghasilkan energi guna membantu manusia untuk mencukupi kebutuhan. Hukum konservasi energi memotivasi manusia terus menciptakan inovasi alat yang lebih efektif dan efisien guna memaksimalkan sumber energi dari alam.

Sifat alami air yang mengalir dari tempat tinggi ke tempat rendah dapat menjadi salah satu sumber energi. Air yang mengalir memiliki energi mekanik yang merupakan pertambahan energi potensial dan energi kinetik dari ketinggian dan kecepatan air tersebut mengalir. Kenaikan kecepatan aliran air akan sekaligus menurunkan tekanan dan energi potensial air berdasarkan hukum Bernoulli (Tipler, 1991). Agar dapat menaikan air menuju ke tempat yang lebih tinggi, maka tekanan air harus diperbesar. Sehingga muncul sebuah alat berupa pompa air guna menyalurkan air ke berbagai tempat sebagai usaha dalam pemenuhan kebutuhan air.

Pompa merupakan alat mekanik yang digunakan untuk mengubah energi mekanik dari motor penggerak menjadi energi tekanan yang mampu menekan air naik dan berpindah ke tempat tertentu (Ginting \& Gultom, 2014). Pompa air yang banyak digunakan saat ini ialah pompa listrik dengan energi penggerak utama 
berupa motor listrik. Pada pompa listrik, energi mekanik untuk menekan air naik dihasilkan melalui motor listrik yang digerakkan menggunakan energi listrik dan bersumber dari PLN. Penggunaan pompa listrik secara otomatis akan menambah beban penggunaan energi listrik rumah tangga masyarakat. Sedangkan, energi listrik yang dipasok dari PLN belum tentu dapat mencukupi kebutuhan energi listrik seluruh masyarakat. Bahkan di beberapa desa-desa kecil sering terjadi pemadaman listrik baik dari PLN atau faktor alam seperti pohon tumbang, hujan, longsor dll. Dikatakan oleh Siahaan dan Sitepu, jika kebutuhan energi listrik dipenuhi dengan alternatif lain seperti mesin diesel, akan terjadi masalah finansial dan daya beli masyarakat yang masih rendah (Siahaan \& Sitepu, 2013).

Pompa hidram (Hydraulic Ram Pump) dapat menjadi solusi untuk mengalirkan air dari tempat rendah ke tempat tinggi dengan energi mekanik dari air sebagai sumber penggerak utamanya. Pompa hidram adalah pompa yang memanfaatkan palu air (water hammer) sebagai tenaga utama untuk menghasilkan tekanan dinamik air sehingga dapat menekan air naik dari sumber air yang tidak terlalu tinggi menuju ke tempat yang lebih tinggi dari sumber air tersebut. Energi yang ditimbulkan dari hantaman air yang mengalir pada ketinggian tertentu akan menghasilkan energi potensial yang membantu air naik (Sofwan \& Siregar, 2015). Dalam perancangan pompa hidram ada beberapa syarat yang harus diperhatikan yaitu ketinggian atau kemiringan terjunan air, kecepatan air mengalir pada pipa, dan besar tekanan air. Perancangan tersebut tersebut telah digunakan dalam penelitian sebelumnya untuk menghasilkan pompa hidram yang baik sebagai sistem pentransmisian air (Kencanawati, H. Mustakim, \& M. Ramdhan, 2016).

Terdapat keuntungan bahwa pompa hidram dapat dibuat dengan bahan-bahan sederhana yang mudah ditemukan dan harga terjangkau. Perangcangan pompa hidram dapat dibuat dengan berbagai ukuran sesuai dengan kebutuhan. Guna mengetahui efisiensi kerja pompa hidram, dapat dilakukan uji coba terlebih dahulu. Setiap pompa hidram memiliki efisiensi kerja yang berbeda dilihat dari perbandingan air masukan (input) dengan air pengeluaran (output) (Supriyanto \& Irawan, 2017). Perbandingan antara air masuk dan air yang naik pada pompa hidram menunjukkan hasil kerja dari unit pompa hidram itu sendiri. Studi ini berfokus pada prinsip kerja pompa hidram yang memanfaatkan palu air dan besar efisiensi kerja dari pompa hidram yang dirancang pada ukuran yang telah ditentukan oleh penulis.

\section{METODE PENELITIAN}

Pompa hidram yang dirancang pada studi ini memiliki beberapa komponen penting meliputi: (1) Pipa masukan, (2) katup limbah, (3) katup penghantar, (4) tabung udara, dan (5) pipa penghantar/keluaran, seperti ditunjukkan pada Gambar 1.

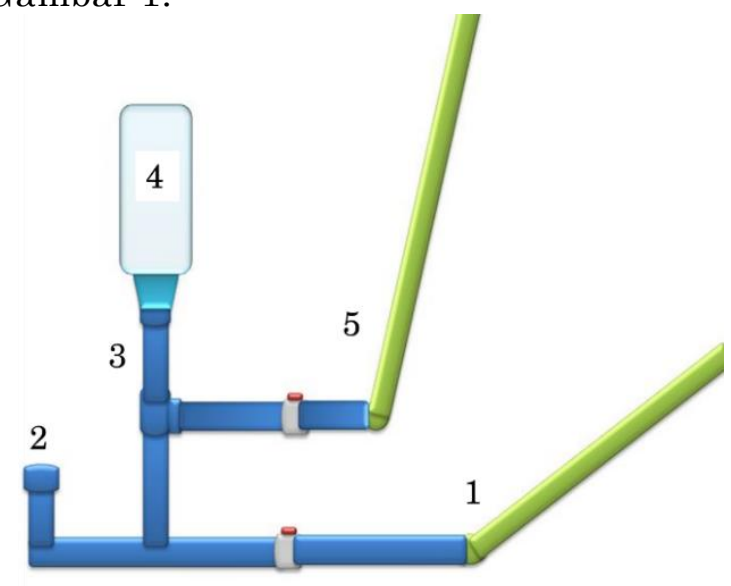

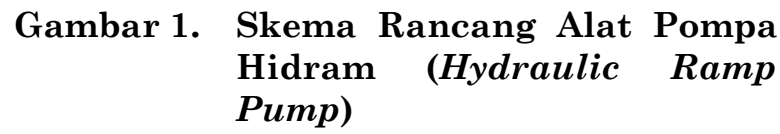

Bahan-bahan yang digunakan untuk membuat pompa hidram rancangan ini adalah: pipa PVC $1 / 2$ inchi masing-masing potongan $15 \mathrm{~cm}, 10 \mathrm{~cm}, 6 \mathrm{~cm}$, dan $5 \mathrm{~cm}$; tee $1 / 2$ inchi; elbow PVC $1 / 2$ inchi; sock drat luar PVC; sock drat dalam; reducer pipa PVC; drop pipa PVC; klem ring; selang masingmasing panjang $1 \mathrm{~m}$ dan $2 \mathrm{~m}$; botol minum bekas volume 1,5 liter; dan lem pipa.

Pada uji eksperimen untuk menentukan efisiensi kerja pompa hidram, diberikan beberapa variasi tekanan-air yang 
masuk ke dalam pompa. Variasi nilai tekanan diukur dan dihitung menggunakan Hukum Toricelli dan persamaan Hukum Bernoulli.

Sebelum mencari tahu besar tekanan air masuk, lebih dahulu kecepatan aliran air $(v)$ dicari dengan mengasumsikan bahwa air yang mengalir dari sumber sebelum ke pipa masukan ialah air yang keluar dari suatu lubang kecil dengan kelajuan tertentu. Waktu $(t)$ untuk air jatuh dari lubang kecil pada ketinggian $(h)$ yang membentuk lintasan setengah parabola dengan jarak jatuh $(x)$ dari posisi vertikal lubang akan sama dengan waktu jatuhnya air itu jika bergerak jatuh bebas (Tipler, 1991). Sehingga dalam menentukan kecepatan aliran air-masuk ke pipa, digunakan hukum Toricelli dan diperoleh persamaan hitung sebagai berikut:

$$
\begin{gathered}
x=v \cdot t \\
v=\sqrt{\frac{x^{2} g}{2 h}}
\end{gathered}
$$

Selanjutnya nilai tekanan-air $(P)$ yang masuk ke dalam pompa dihitung menggunakan persamaan hukum Bernoulli berikut:

$$
\begin{aligned}
& P+\rho g h+\frac{1}{2} \rho v^{2}=P_{a t m} \\
& P=P_{a t m}-\rho g h-\frac{1}{2} \rho v^{2}
\end{aligned}
$$

Efisiensi kerja dari rancangan pompa hidram dapat diketahui dengan menganalisis nilai debit air limbah $\left(Q_{L}\right)$, debit air naik $\left(Q_{N}\right)$, dan debit air masuk $\left(Q_{M}\right)$. Masing-masing nilai tersebut diperoleh dengan menghitung volume air terbuang $\left(V_{L}\right)$, volume air naik $\left(\left(V_{N}\right)\right.$, dan volume air masuk $\left(\left(V_{M}\right)\right.$ tiap satuan waktu selama kerja diamati. Persamaan untuk menentukan debit masing-masing adalah:

$$
\begin{gathered}
Q_{L}=\frac{V_{L}}{t} \\
Q_{N}=\frac{V_{N}}{t} \\
Q_{M}=Q_{L}+Q_{N}
\end{gathered}
$$

Selanjutnya menghitung efisiensi kerja rancangan pompa hidram dengan membandingkan antara nilai debit air masuk dengan nilai debit air naik. Nilai efisiensi kerja pada uji eksperimen ini dihitung melalui dua cara, pertama dengan menggunakan persamaan:

$$
\eta=\frac{Q_{N}}{Q_{M}} \times 100 \%
$$

dan kedua dengan mengolah data table untuk membuat grafik linear. Menggunakan persamaan garis lurus:

$$
y=m \cdot x
$$

kemudian di baca pada pada grafik tersebut. Dengan mengasumsikan bahwa $y$ adalah volume air naik $\left(V_{N}\right)$ dan $x$ adalah volume air masuk $\left(V_{M}\right)$, maka efisiensi kerja $(\eta)$ diperoleh dengan menentukan nilai gradien garis $(m)$ dikalikan seratus persen.

$$
\begin{gathered}
Q_{N}=\eta \cdot Q_{M} \\
V_{N} \cdot t=\eta \cdot V_{M} \cdot t \\
V_{N}=\eta \cdot V_{M}
\end{gathered}
$$

Analisis data yang digunakan dalam uji eksperimen rancangan pompa hidram ini adalah statistik deskriptif kuantitatif. Statistik deskriptif digunakan untuk menganalisis data secara deskriptif dari data yang telah dikumpulkan (Sugiyono, 2018). Data hasil uji eksperimen berupa data kuantitatif disajikan dalam bentuk tabel dan grafik.

\section{HASIL DAN PEMBAHASAN}

Hasil rancangan Hydraulic Ram Pump dengan Water Hammer yang telah dilakukan uji efisiensi dalam studi ini ditampilkan pada Gambar 2. Prinsip kerja dari pompa hindram rancangan tersebut yaitu pertama-tama air masuk melalui pipa masukan (1) dari suatu ketinggian. Diilustrasikan pula pada gambar 1 bahwa pipa masukan posisinya miring menurun sehingga air dengan mudah terdorong masuk akibat gaya gravitasi. Air yang membawa energi potensial menekan masuk menuju pompa dan mendorong klep di katup limbah (2) hingga klep terbuka. Sebagian air yang masuk ke katup limbah terdorong ke luar dan menekan balik sehingga kelp di katup limbah tertutup. 
Setelah klep katup limbah tertutup, air di dalam pompa bertekanan tinggi memaksa klep di katup penghantar (3) terbuka. Kemudian air naik ke katup penghantar hingga udara di dalam tabung udara (4) tertekan. Saat udara bertekanan tinggi, udara akan mendorong balik air yang menyebabkan klep di katup penghantar kembali tertutup sehingga air yang telah masuk melewati katup penghantar akan terdorong ke pipa penghantar/keluaran (5) dan air berhasil mengalir ke tempat yang tinggi. Proses tersebut terjadi dalam satu siklus dan kemudian terulang siklus berikutnya secara terus-menerus hingga air dari tempat yang rendah dapat dialirkan ke tempat yang tinggi.

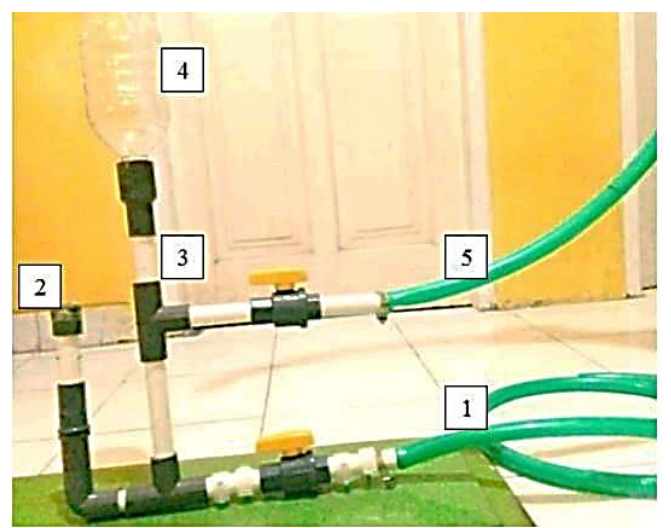

Gambar 2. Alat Hydraulic Ramp Pump dengan Watter Hammer

Terdapat beberapa konsep yang mempengaruhi kerja dari pompa hidram rancangan ini serta penting untuk diperhatikan agar pompa bekerja dengan baik. Selama siklus berlangsung, ketika katup limbah menutup dengan sangat cepat, kemudian mengakibatkan aliran air dalam pompa (pipa penggerak) berhenti dengan tiba-tiba, maka akan terjadi lonjakan tekanan yang disebabkan dari inersia air dalam pompa, fenomena ini disebut sebagai palu air (water hammer) yang menjadi penggerak utama untuk memompa air dalam hidram (Inthachot, Saehaeng, Max, Muller, \& Spreer, 2015). Terdapat pula kondisi sesaat setelah katup limbah tertutup, kemudian energi kinetik yang tersisa diubah menjadi energi potensial yang mampu mendorong air melewati katup penghantar menuju ke dalam tabung udara (Sucipta, Suarda, \& Suweden, 2019). Air di dalam tabung udara ini akan diseimbangkan tekanannya oleh udara. Peran dari ruang udara pada rancang ini dapat mencegah terjadinya gelombang tekanan kejut di pipa keluaran serta meningkatkan efisiensi pemompaan secara keseluruhan dan memungkinkan aliran air yang lebih konstan di pipa pengeluaran (Viccione, Immediata, Cava, \& Piantedosi, 2018). Diharapkan dengan pemanfaatan ruang udara ini tekanan udara menjadi maksimal sehingga dapat menutup katup penghantar dan lebih banyak air air naik melalui pipa penghantar/keluaran.

Hasil uji eksperimen efisiensi pompa hidram dari rancangan alat yang ditunjukkan pada gambar 2 , diperoleh data berupa volume air-limbah $\left(V_{L}\right)$, volume airnaik $\left(V_{N}\right)$, volume air-masuk $\left(V_{M}\right)$, debit airlimbah $\left(Q_{L}\right)$, debit air-naik $\left(Q_{N}\right)$, dan debit air-masuk $\left(Q_{M}\right)$ pada variasi tekanan air $(P)$ yang berbeda.

Variasi tekanan air ditentukan secara konvensional tanpa menggunakan alat pengukur tekanan air. Dalam penentuan besar tekanan air dengan metode konvensional, digunakan hukum Torricelli seperti pada persamaan (1) untuk menentukan besar kecepatan aliran air. Kecepatan aliran air tersebut diketahui setelah variabel $x$ sebagai jarak pancuran air yang keluar pertama kali dan variabel $t$ sebagai waktu yang diperlukan pancuran air keluar hingga menyentuh tanah diukur. Pengukuran variabel $x$ dilakukan menggunakan penggaris dengan ketelitian 0.5 mm dan pengukuran variabel $t$ dilakukan menggungakan stopwatch dengan ketelitian 0.5 detik.

Melalui data kecepatan aliran air serta tinggi lubang pancuran air ke permukaan tanah, besar tekanan air dari pipa masukan dapat diketahui dengan menggunakan persamaan (3) Hukum Bernoulli. Digunakan empat variasi tekanan air pada eksperimen menentukan efisiensi pompa hidram ini. Nilai variasi tekanan I, II, III, dan IV berturut-turut: 98,385 $\mathrm{Pa}, 98,365$ $\mathrm{Pa}, 98,195 \mathrm{~Pa}$, dan 98,156 $\mathrm{Pa}$.

Pada uji eksperimen yang pertama, proses pemompaan air dilakukan selama 30 detik untuk mengetahui jumlah volume 
air-naik $\left(Q_{N}\right)$ dari setiap variasi tekanan. Diperoleh nilai volume air dan nilai debit air pada setiap variasi tekanan selama proses pemompaan dalam waktu konstan $t$.

Tabel 1. Debit Air Naik pada Waktu Konstan

\begin{tabular}{ccccccc}
\hline $\begin{array}{c}\text { Variasi } \\
\text { Tekanan }\end{array}$ & $\mathbf{V}_{\mathbf{N}}$ (liter) & $\mathbf{V}_{\mathbf{L}}$ (liter) & $\begin{array}{c}\mathbf{Q M}_{\mathbf{M}} \\
(\mathbf{l i t e r} / \mathbf{s})\end{array}$ & $\begin{array}{c}\mathbf{Q}_{\mathbf{N}} \\
(\text { liter/s) }\end{array}$ & $\begin{array}{c}\mathbf{Q}_{\mathbf{L}} \\
\text { (liter/s) }\end{array}$ & t (s) \\
\hline I & 0 & 1.225 & $2.10 \times 10^{-2}$ & 0 & $4.08 \times 10^{-2}$ & 30 \\
II & 0.086 & 1.575 & $5.30 \times 10^{-2}$ & $0.29 \times 10^{-2}$ & $5.08 \times 10^{-2}$ & 30 \\
III & 1.750 & 1.050 & $12.04 \times 10^{-2}$ & $5.80 \times 10^{-2}$ & $3.50 \times 10^{-2}$ & 30 \\
IV & 2.700 & 1.650 & $14.50 \times 10^{-2}$ & $9.00 \times 10^{-2}$ & $5.50 \times 10^{-2}$ & 30 \\
\hline
\end{tabular}

Berdasarkan data tabel 1 pada variasi tekanan air masukan I, $\mathbf{V}_{\mathbf{N}}$ bernilai nol. Hal tersebut berkaitan dengan nilai $Q_{N}$ yang sama dengan nol, artinya tidak ada debit air dan volume air yang naik ke pipa penghantar/keluaran selama 30 detik pertama pompa hidram bekerja dengan variasi tekanan I. Nilai $V_{N}$ tertinggi selama eksperimen ini diperoleh dari variasi tekanan
IV di mana sebanyak 2.7liter air naik ke pipa keluaran selama 30 detik pompa hidram tersebut bekerja.

Pada uji eksperimen yang kedua, variabel konstan ditetapkan pada volume air-naik $\mathrm{V}_{\mathrm{N}}$ sebesar 0.35 liter untuk mengetahui waktu yang diperlukan dari setiap variasi tekanan dalam proses pemompaan hingga mencapai $\mathrm{V}_{\mathrm{N}}$ tersebut.

Tabel 2. Waktu Air Naik pada Volume Air Naik Konstan

\begin{tabular}{ccccccc}
\hline $\begin{array}{c}\text { Variasi } \\
\text { Tekanan }\end{array}$ & $\mathbf{V}_{\mathbf{N}}$ (liter) & $\mathbf{V}_{\mathbf{L}}$ (liter) & $\begin{array}{c}\mathbf{Q M}_{\mathbf{M}} \\
\text { (liter/s) }\end{array}$ & $\begin{array}{c}\mathbf{Q}_{\mathbf{N}} \\
\text { (liter/s) }\end{array}$ & $\begin{array}{c}\mathbf{Q L}_{\mathbf{L}} \\
\text { (liter/s) }\end{array}$ & t (s) \\
\hline I & 0.35 & 2.45 & $2.10 \times 10^{-2}$ & $0.26 \times 10^{-2}$ & $1.84 \times 10^{-2}$ & 133 \\
II & 0.35 & 1.40 & $5.30 \times 10^{-2}$ & $1.06 \times 10^{-2}$ & $4.24 \times 10^{-2}$ & 33 \\
III & 0.35 & 0.61 & $12.04 \times 10^{-2}$ & $4.38 \times 10^{-2}$ & $7.66 \times 10^{-2}$ & 8 \\
IV & 0.35 & 0.22 & $14.50 \times 10^{-2}$ & $8.75 \times 10^{-2}$ & $5.50 \times 10^{-2}$ & 4 \\
\hline
\end{tabular}

Data hasil uji eksperimen kedua yang disajikan pada tabel 2 menunjukan bahwa variasi tekanan IV membutuhkan waktu 4 detik untuk mencapai $\mathrm{V}_{\mathrm{N}} 0.35$ liter, sedangkan variasi tekanan I membutuhkan waktu 133 detik untuk mencapai $\mathrm{V}_{\mathrm{N}} 0.35$ liter. Data tersebut menunjukkan bahwa variasi tekanan I paling cepat dalam memompa air naik dibandingkan dengan variasi tekanan lainnya.

Berdasarkan hasil uji eksperimen 1 dan 2, diketahui bahwa variasi tekanan IV memberikan nilai $\mathrm{V}_{\mathrm{N}}$ dan $\mathrm{Q}_{\mathrm{N}}$ yang paling tinggi diantara variasi tekanan lainnya serta waktu $t$ paling cepat untuk menaikkan sejumlah air pada volume yang sama. Melalui pertimbangan tersebut, pada uji eksperimen untuk menentukan efisiensi kerja dari rancangan Hydraulic Ram Pump dengan Water Hammer ini menggunakan tekanan air variasi tekanan IV yaitu sebesar 98,156 Pa.
Tabel 3. Volume Air Masuk dan Volume Air Naik pada Tekanan Konstan

\begin{tabular}{cccc}
\hline No & $\mathbf{V}_{\mathbf{M}}$ (liter) & $\mathbf{V}_{\mathbf{N}}$ (liter) & $\mathbf{V}_{\mathbf{L}}$ (liter) \\
\hline 1. & 2.90 & 1.80 & 1.10 \\
\hline 2. & 5.10 & 3.00 & 2.10 \\
\hline 3. & 8.10 & 4.40 & 3.70 \\
\hline 4. & 10.30 & 5.60 & 5.10 \\
\hline 5. & 13.30 & 6.70 & 6.60 \\
\hline 6. & 15.90 & 7.80 & 8.10 \\
\hline 7. & 18.30 & 9.00 & 9.30 \\
\hline 8. & 21.06 & 10.21 & 10.85 \\
\hline 9. & 23.82 & 11.42 & 12.40 \\
\hline 10. & 26.57 & 12.62 & 13.95 \\
\hline 11. & 28.97 & 13.52 & 15.45 \\
\hline 12. & 31.23 & 14.48 & 16.75 \\
\hline 13. & 33.78 & 15.38 & 18.40 \\
\hline 14. & 36.39 & 16.34 & 20.05 \\
\hline 15. & 38.99 & 17.29 & 21.70 \\
\hline $\boldsymbol{\Sigma}$ & $\mathbf{3 1 4 . 7 1}$ & $\mathbf{1 4 9 . 5 6}$ & $\mathbf{1 6 5 . 0 5}$ \\
\hline & & &
\end{tabular}




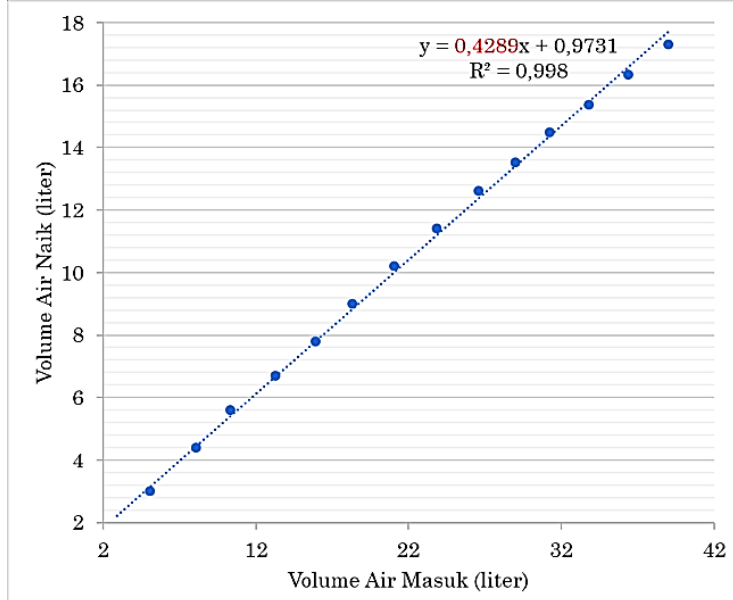

Gambar 3. Grafik Efisiensi Kerja Pompa Hidram

Dengan menggunakan persamaan garis lurus $y=m . x$ dan mengasumsikan bahwa efisiensi kerja pompa hidram sama dengan gradien garis berdasarkan suatu grafik, efisiensi kerja dari pompa hidram dapat diperoleh dengan menggunakan persamaan (11). Dari nilai persamaan garis yang disajikan dalam grafik pada gambar 3 dapat kita ketahui bahwa efisiensi kerja pompa hidram hasil uji eksperimen ini sebesar $42.89 \%$.

Besar efisiensi kerja pompa hidram yang diperoleh dari rancangan ini relatif rendah. Hal tersebut dapat dikarenakan tidak semua air yang masuk disalurkan ke pipa penghantar akibat adanya air yang terbuang melalui katup limbah. Katup limbah yang terbuka saat proses pemompaan dapat menjadi penyebab utama rendahnya efisiensi kerja dari pompa hidram ini, sebagaimana alasan yang terjadi pada percobaan serupa (Taufiq, Putra, \& Suriansyah, 2016). Karena banyaknya air masuk yang terbuang di katup limbah, air yang naik ke katup penghantar tidak sebanyak air masuk dan volume air yang naik lebih sedikit daripada volume air yang masuk. Efisiensi kerja dari rancangan Hydraulic Ram Pump dengan Water Hammer ini dipengaruhi oleh beberapa faktor antara lain tinggi dari pipa penghantar/keluaran, diameter pipa, jenis pipa, karakteristik katup limbah, dan panjang pipa pada katup limbah. Herawati dalam penelitiannya pernah mengujicobakan efisiensi kerja pompa hidram tersebut berdasarkan panjang pipa inlet (Herawati, Kuswartomo, \& Wibowo, 2011).

\section{Penutup}

Berdasarkan uji eksperimen pada studi ini, diperoleh nilai tekanan air masukan yang baik dari beberapa variasi tekanan. Variasi tekanan yang digunakan untuk menguji efisiensi kerja dari pompa hidram adalah variasi IV dengan nilai tekanan 98,156 Pa. Tekanan variasi IV ini dapat mencapai $V_{N}$ sebesar 2.70 liter dalam waktu 30 detik dan $V_{N}$ sebesar 0.35 liter dalam waktu tersingkat yaitu 4 detik. Sehingga diperoleh efisiensi kerja pompa hidram pada uji eksperimen tekanan konstan 98,156 $\mathrm{Pa}$ adalah 46.5\%. Efisiensi kerja pompa hidram yang dihasikan relatif rendah, hal tersebut dikarenakan selama proses pemompaan volume air masuk tidak sebanyak volume air naik karena sisanya terbuang selama proses pemompaan di badan hidram.

\section{Referensi}

Ginting, S. A., \& Gultom, M. S. (2014). Analisa Pengaruh Variasi Volume Tabung Udara dan Variasi Beban Katup Limbah Terhadap Performa Pompa Hidram. Jurnal E-Dinamis 9(1), 47-56.

Herawati, Y., Kuswartomo, \& Wibowo, G. D. (2011). Panjang Pipa Inlet Terhadap Efisiensi Pompa Hidram. Dinamika Teknik Sipil 11(2), 128134.

Inthachot, M., Saehaeng, S., Max, J. F., Muller, J., \& Spreer, W. (2015). Hydraulic Ram Pumps for Irrigation in Nothtern Thailand. Agriculture and Agricultural Science Procedia 5(1), 107-114.

Kencanawati, M., H. Mustakim, \& M. Ramdhan. (2016). Analisis Sistem Distribusi Air Bersih Berdasarkan Parameter Debit dan Tekanan Air (Studi Kasus Perumahan Nusantara Lestari km 8 Balikpapan). Jurnal Transukma 02(01), 1-6. 
Siahaan, P., \& Sitepu, T. (2013). Rancang Bangun dan Uji Eksperimental Pengaruh Variasi Panjang Driven Pipe dan Diameter Air Chamber Terhadap Efisiensi Pompa Hidram. Jurnal Dinamis 2(12).

Sofwan, M., \& Siregar, I. H. (2015). Pengaruh Ketinggian Terjunan dan Volume Tabung Udara Terhadap Kinerja Pompa Hidram. JTM 03(03), 16-24.

Sucipta, M., Suarda, M., \& Suweden, I. N. (2019). Pengaruh Diameter Lubang Snifter-Valve Terhadap Peningkatan Tekanan Dalam Tabung Udara Pompa Hidram. Jurnal Energi dan Manufaktur 12(01), 41-46.

Sugiyono. (2018). Metode Penelitian Kombinasi (Mixed Methods). Bandung: Alfabeta.

Supriyanto, A., \& Irawan, D. (2017). Pengaruh Variasi Jarak Sumbu Katup Limbah dengan Sumbu Tabung Udara Terhadap Efisiensi Pompa Hidram Turbo. Jurnal Teknik Mesin 6(02), 185-192.

Taufiq, M., Putra, T. D., \& Suriansyah. (2016). Pengaruh Variasi Jarak Kerja Katup Penghantar (Delivery Valve) Terhadap Kinerja Pompa Hidram. Widya Teknika 24(2), 3337.

Tipler. (1991). Fisika Jilid 1 (Edisi 3). Jakarta: Erlangga.

Viccione, G., Immediata, N., Cava, R., \& Piantedosi, M. (2018). A Preliminary Laboratory Investigation of A Hydraulic Ram Pump. The 3rd EWaS International Conference on "Insights on the Water-Energy-Food Nexus" (pp. 1-7). Lefkada Island, Greece: MDPI Proceedings 2018, 2, 687. 